\title{
Hubungan Pemberian Discharge Planning dengan Kecemasan pada Pasien Diabetes Melitus
}

\author{
Yashinta Setiyani ${ }^{1}$, Fatma Siti Fatimah1, Sumarsi \\ 1 Universitas Alma Ata \\ ${ }^{2}$ RSUD Wates \\ EMail: fatmasitifatimah@gmail.com
}

\begin{abstract}
Abstrak
Diabetes melitus penyakit tidak menular yang sifatnya kronik, bila tidak mendapatkan penatalaksanaan yang baik akan terjadi komplikasi pada seluruh bagian tubuh bahkan hingga kematian. Pasien diabetes melitus yang menjalani rawat inap akan mengalami masalah secara fisiologis maupun psikologis. Salah satu masalah psikologis pada pasien diabetes yang menjalani rawat inap adalah kecemasan. Suatu metode dalam pelayanan keperawatan untuk mengidentifikasi kebutuhan pasien baik kebutuhan fisik maupun psikologis pasien yang dilakukan sejak pasien tersebut masuk ke rawat inap hingga pasien dinyatakan boleh pulang dilakukan melalui discharge planning. Tujuanpenelitian ini untuk mengetahuihubungan pemberiandischarge planning dengan kecemasan pada pasien diabetes melitus di RS Mata "Dr.YAP" Yogyakarta. Jenis penelitian yang digunakan adalah penelitian kuantitatif dengan menggunakan desain penelitian Cross sectional. Populasi dalam penelitian ini adalah pasien kasus mata dengan diabetes melitus yang dirawat di ruang rawat inap di RS Mata "Dr.YAP" Yogyakarta dengan sampel sebanyak 30 orang dengan teknik pengambilan sampel menggunakan Accidental sampling. Instrumen penelitian yang digunakan adalah kuesioner. Hasil penelitian menunjukkan bahwa responden yang diberikan discharge planningy ang baik, tidak memiliki kecemasan sebesar $70 \%$. Analisis data menggunakan uji statistik Chi-square dengan nilai $p$-value 0,010 . Kesimpulannya terdapat hubungan antara pemberian discharge planning dengan kecemasan pada pasien diabetes melitus di Rumah Sakit Mata "Dr.YAP" Yogyakarta.
\end{abstract}

Kata Kunci: diabetes melitus, kecemasan, discharge planning

\section{The Relation of Discharge Planning with Anxiety on The Patiens with Diabetes Mellitus}

\begin{abstract}
Diabetes Mellitus is a non-communicable disease that is chronic, when not getting good management will occur complications in all parts of the body even to death. Patients with diabetes mellitus who undergo inpatient will experience problems both physiologically and psychologically. One of the psychological problems in patients with diabetes mellitus undergoing hospitalization is anxiety. A method in nursing service to identify patient needs both physical and psychological needs of patients performed since the patient went into hospitalization until the patient is declared to go home through discharge planning. Determine the relationship of discharge planning with anxiety in patients with diabetes mellitus at "Dr.YAP" Eye Hospital Yogyakarta. The study design was quantitative with cross sectional approach. Research population was patients of eye case with diabetes mellitus which is hospitalized in "Dr.YAP" Eye Hospital Yogyakarta, with sample counted 30 people. The data was collected with acidental sampling technique. The instrument used is questionnaire of discharge planning and questionnaire of anxiety rating scale. The result showed that respondents given discharge planning well, do not had anxiety of $70 \%$. Data analysis used Chi-square with $p$-value 0,010 which means there was relation between discharge planning with anxiety on the patients with diabetes mellitus at "Dr. YAP" Eye Hospital Yogyakarta.
\end{abstract}

Keywords: diabetes mellitus, anxiety, discharge planning

Received: 29/08/2018; published: 28/10/2018

Setiyani, Y., Fatimah F.S., Sumarsi. 2018. Indonesian Journal of Hospital Administration

Vol. 1 No.2 I 89 


\section{PENDAHULUAN}

Diabetes melitus merupakan gangguan kesehatan yang berupa kumpulan gejala yang disebabkan oleh peningkatan kadar gula darah akibat kekurangan ataupun resistensi insulin. Penyakit diabetes melitus telah menjadi penyakit masyarakat umum, menjadi beban kesehatan masyarakat, meluas dan membawa banyak kecacatan dan kematian (1). Diabetes melitus merupakan salah satu jenis penyakit metabolik yang selalu mengalami peningkatan setiap tahunnya, baik di Indonesia maupun di dunia. Menurut International Diabetes Federation (IDF), diabetes melitus telah menyerang 415 juta orang di dunia pada tahun 2015 , dan jumlah ini diperkirakan meningkat menjadi 642 juta (55\%) pada tahun 2020 mendatang (2).

meningkatkan kadar gula darah pasien $(3,4)$. Masalah kecemasan pasien dapat diidentifikasi oleh perawat sejak pasien masuk di rawatinap, selama proses perawatan hingga menjelang kepulangan pasien. Metode dalam pelayanan keperawatan untuk mengidentifikasi kebutuhan pasien baik kebutuhan fisik maupun psikologis dimana salah satunya adalah kecemasan pasien yang dilakukan sejak pasien tersebut masuk ke rawat inap hingga pasien dinyatakan boleh pulang dilakukan melalui discharge planning. Discharge planning adalah proses mempersiapkan pasien untuk meninggalkan satu unit pelayanan kepada unit yang lain didalam atau diluar suatu agen pelayanan kesehatan umum (5).

Di Indonesia pada tahun 2013 penderita DM mencapai 10 juta orang dan diperkirakan terus meningkat sampai dengan tahun 2030, sehingga akan menjadikan Indonesia sebagai negara peringkat tujuh dari 10 negara penyandang DM terbesar dunia (6). Menurut data dari Riset Kesehatan Dasar (RIKESDAS) tahun 2013 tingkat prevalensi penderita diabetes melitus sebesar 6,8\% dari 255.461.686 jumlah penduduk di Indonesia atau sekitar 17 juta penduduk usia produktif yang menderita diabetes melitus (7). Angkakejadian diabetes melitus di Daerah Istimewa Yogyakarta sebesar 2,6\% dari 3.679.176 jumlah penduduk DIY dan menempati urutan pertama dari seluruh provinsi yang ada di Indonesia.

Diabetes melitus merupakan penyakit yang sifatnya kronik, dimana bila tidak mendapatkan penatalaksanaan yang baik akan terjadi komplikasi yang bisa mengenai seluruh bagian tubuh. Kerusakan jangka panjang yang ditimbulkan karena masalah ini antara lain terjadinya disfungsi atau kegagalan organ mata, ginjal, jantung, saraf dan pembuluh darah (8). Banyaknya komplikasi juga memberikan kontribusi terhadap perubahan fisik, psikologis dan kehidupan sosial pasien. Perubahan psikologis yang terjadi pada pasien dengan diabetes melitus salah satu diantaranya adalah kecemasan. Kecemasan merupakan respon individu terhadap suatu keadaan yang membuat tidak nyaman yang dialami oleh seseorang berkaitan dengan perasaan yang tidak pasti dan tidak berdaya yang dapat disebabkan salah satunya 
karena proses pengobatan seperti pada pasien dengan diabetes melitus yang menjalani perawatan di rumah sakit (9).

Penanganan kecemasan pada pasien diabetes mellitus sangatlah diperlukan karena pada pasien diabetes melitus yang mengalami kecemasan akan terjadi respon fisiologis berupa peningkatan glikogenolis menjadi glukosa bebas yang dapat meningkatkan kadar gula darah pasien (3). Masalah kecemasan pasien dapat diidentifikasi oleh perawat sejak pasien masuk di rawat inap, selama proses perawatan hingga menjelang kepulangan pasien. Metode dalam pelayanan keperawatan untuk mengidentifikasi kebutuhan pasien baik kebutuhan fisik maupun psikologis dimana salah satunya adalah kecemasan pasien yang dilakukan sejak pasien tersebut masuk ke rawat inap hingga pasien dinyatakan boleh pulang dilakukan melalui discharge planning. Discharge planning adalah proses mempersiapkan pasien untuk meninggalkan satu unit pelayanan kepada unit yang lain didalam atau diluar suatu agen pelayanan kesehatan umum (4).

\section{BAHAN DAN METODE}

Jenis penelitian ini adalah penelitian kuantitatif rancangan penelitian ini adalah cross sectional (10). Penelitian ini telah dilaksanakan di ruang rawat inap RS Mata "Dr.YAP" Yogyakarta pada tanggal Januari dan Februari 2018. Jumlah sampel sebanyak 30 pasien dan menggunakan total sampel.

\section{HASIL DAN PEMBAHASAN}

Responden dalam penelitian ini adalah pasien kasus mata dengan diabetes melitus. Secara lengkap karakteristik responden akan disajikan dalam tabel berikut:

Tabel 1. Distribusi Frekuensi Karakteristik Responden

\begin{tabular}{llll}
\hline \multicolumn{2}{l}{ Krakteristik Responden } & $\mathbf{n}$ & $\%$ \\
\hline Jenis Kelamin & Laki laki & 12 & 40 \\
& Perempuan & 18 & 60 \\
Usia & $17-25$ tahun & 2 & 6.7 \\
& $36-45$ tahun & 6 & 20 \\
& $46-55$ tahun & 9 & 30 \\
& $56-65$ tahun & 11 & 36.6 \\
Pendidikan & $>65$ tahun & 2 & 6.7 \\
& SD & 1 & 3.3 \\
& SMP & 7 & 23.3 \\
& SMA & 10 & 33.3 \\
& Perguruan Tinggi & 12 & 40 \\
& Tidak Bekerja & 9 & 30 \\
& PNS & 7 & 23.3 \\
& Wiraswasta & 6 & 20 \\
& Buruh & 8 & 26.7 \\
\hline
\end{tabular}

Berdasarkan Tabel 1 menunjukan bahwa sampel terbanyak berusia 56-65 tahun sebanyak 11 orang dengan persentase $36,6 \%$. Sampel terbanyak berjenis kelamin 
perempuan sebanyak 18 orang dengan persentase $60 \%$. Sampel yang berpendidikan perguruan tinggi sebanyak 12 orang dengan persentase $40 \%$. Dan sampel yang terbanyak adalah tidak bekerja sebanyak 9 orang dengan persentase $30 \%$.

Pembagian karakteristik usia responden berdasarkan pengelompokan usia menurut Depkes tahun 2009. Hasil distribusi frekuensi responden pada penelitian ini berdasarkan Tabel 1 menunjukkan bahwa dari 30 responden mayoritas responden dengan usia 5665 tahun sebanyak 11 orang (36,6\%). Hal ini sesuai dengan teori yang mengatakan bahwa kematangan individu dalam proses berpikir individu yang berusia menggunakan mekanisme koping yang baik dibandingkan kelompok umur dibawahnya (11). Mekanisme koping merupakan bentuk pengendalian diri individu terhadap perubahan yang dihadapi (11). Hasil penelitian ini didukung dengan hasil penelitian sebelumnya yang dilakukan oleh Lutfa dimana usia pasien terbanyak $>40$ tahun sebanyak 20 orang $(45,5 \%)$ dan korelasi antara usia pasien dengan kecemasan pasien diperoleh nilai koefisien $r=-0,592$ sehingga uji korelasi bermakna semakin bertambah usia pasien maka ada kecenderungan kecemasan pasien akan menurun (12). Berdasarkan uraian di atas, peneliti berpendapat bahwa semakin dewasa usia responden maka mekanisme koping individu semakin baik sehingga dapat menurunkan kecemasan.

Hasil distribusi frekuensi responden pada penelitian ini berdasarkan Tabel 1 menunjukkan bahwa mayoritas responden berjenis kelamin perempuan sebanyak 18 orang (60\%). Peneliti berpendapat bahwa perempuan secara psikologis lebih mudah untuk cemas dibandingkan dengan laki-laki. Berdasarkan teori mengatakan bahwa kecemasan terjadi lebih banyak pada kecemasan yang tinggi dikarenakan akibat dari reaksi saraf otonom yang berlebihan dengan naiknya sistem simpatis, naiknya norepineprin, terjadi peningkatan pelepasan katekolamin dan adanya gangguan regulasi serotonergik yang abnormal (13). Hal ini sejalan dengan hasil penelitian sebelumnya yang dilakukan oleh Demak tentang hubungan antara jenis kelamin dengan kecemasan mahasiswa di Fakultas Kedokteran dan IImu Kesehatan Program Studi Pendidikan Dokter Palu didapatkan jumlah responden jenis kelamin perempuan sebanyak 72 orang $(65,45 \%)$. Hal ini menunjukkan ada hubungan antara jenis kelamin dengan tingkat kecemasan (14). Berdasarkan uraian di atas maka peneliti berpendapat bahwa jenis kelamin perempuan lebih mudah mengalami kecemasan dibanding dengan responden berjenis kelamin laki-laki.

Hasil distribusi frekuensi responden pada penelitian ini berdasarkan tabel 1 menunjukkan bahwa mayoritas responden berpendidikan perguruan tinggi sebanyak 12 orang (40\%). Hal ini didukung dengan penelitian sebelumnya yang dilakukan oleh Lutfa korelasi antara pendidikan pasien dengan tingkat kecemasan pasien yang menjalani kemoterapi diperoleh jumlah tingkat pendidikan terbanyak adalah sekolah menengah atas 
sebanyak 27 orang $(61,4 \%)$ dengan hasil koefisien $r=-0,563$ dengan nilai $p$ sebesar 0,038 . Arah korelasi adalah negatif sehingga uji korelasi bermakna semakin tinggi tingkat pendidikan pasien maka ada kecenderungan tingkat kecemasan pasien semakin menurun (12). Menurut Notoatmojo, bahwa pendidikan seseorang berperan dalam membentuk sikap dan perilaku seseorang dalam berinteraksi dengan lingkungan. Karena hasil pendidikan ikut membentuk pola pikir, pola persepsi dan sikap pengambilan keputusan seseorang. Pendidikan seseorang yang meningkat mengajarkan individu mengambil sikap keputusan yang terbaik untuk dirinya (15). Berdasarkan uraian di atas, peneliti berpendapat bahwa makin tinggi tingkat pendidikan responden maka makin rendah tingkat kecemasannya. Hasil distribusi frekuensi responden pada penelitian ini berdasarkan tabel 2 menunjukkan bahwa mayoritas responden tidak bekerja sebanyak 9 orang (30\%). Angka terbanyak kedua adalah responden yang bekerja sebagai buruh yaitu sebanyak 8 orang $(26,7 \%)$.

Tabel 2. Discharge Planning pada pasien diabetes melitus di RS Mata "Dr.YAP" Yogyakarta

\begin{tabular}{lll}
\hline Discharge Planning & $\mathbf{n}$ & $\%$ \\
\hline Baik & 29 & 96.7 \\
Kurang Baik & 1 & 3.3 \\
\hline Total & 30 & 100 \\
\hline
\end{tabular}

Berdasarkan Tabel 2 menunjukan bahwa Discharge Planning yang diberikan kepada sampel penelitian sebagian besar dalam kategori baik yaitu sebanyak 29 orang dengan persentase 96,7\%. Discharge planning adalah proses antisipasi dan perencanaan yang dibutuhkan pasien dan keluarga setelah kembalikerumah, yang merupakan bagian penting dalam perawatan kesehatan secata komprehensif dan harus dilakukan pada setiap perencanaan perawatan pasien (16). Hasil distribusi frekuensi responden pada penelitian ini berdasarkan Tabel 2 menunjukkan bahwa pemberian discharge planning sudah baik yaitu sebesar $96,7 \%$. Hasil penelitian ini menunjukkan bahwa pemberian discharge planning yang baik mulai dari pengkajian hingga evaluasi dapat menurunkan kecemasan pada pasien diabetes melitus yang dilakukan rawat inap.

Tabel 3. Kecemasan pada pasien diabetes melitus di RS Mata "Dr.YAP" Yogyakarta

\begin{tabular}{lll}
\hline Kecemasan & $\mathbf{n}$ & $\%$ \\
\hline Tidak cemas & 21 & 70 \\
Ringan & 6 & 20 \\
Sedang & 3 & 10 \\
\hline Total & 30 & 100 \\
\hline
\end{tabular}

Berdasarkan Tabel 3 menunjukkan distribusi frekuensi kecemasan sampel penelitian berada pada tingkat kecemasan tidak ada kecemasan sebanyak 21 orang dengan persentase $70 \%$. Kecemasan adalah kekhawatiran yang penyebabnya tidak jelas dan menyebar, berkaitan dengan perasaan tidak pasti dan tidak berdaya, keadaan emosi ini tidak memiliki objek yang spesifik (17). Hasil distribusi frekuensi responden pada penelitian ini berdasarkan Tabel 3 
menunjukkan bahwa diketahui tidak ada kecemasan pada pasien dengan diabetes melitus yang diberikan discharge planning dengan baik yaitu sebesar $70 \%$

Tabel 4. Pemberian Discharge Planning Dengan Kecemasan Pada Pasien Diabetes Melitus di RS Mata "Dr.YAP Yogyakarta

\begin{tabular}{|c|c|c|c|c|c|c|c|c|}
\hline \multirow{3}{*}{$\begin{array}{l}\text { Pemberian } \\
\text { discharge } \\
\text { planning }\end{array}$} & \multicolumn{6}{|c|}{ Kecemasan } & \multirow[t]{2}{*}{$\mathbf{R}$} & \multirow{2}{*}{$\begin{array}{l}P \\
\text { value }\end{array}$} \\
\hline & \multicolumn{2}{|c|}{$\begin{array}{l}\text { Tidak } \\
\text { Cemas }\end{array}$} & \multicolumn{2}{|c|}{ Ringan } & \multicolumn{2}{|c|}{ Sedang } & & \\
\hline & $n$ & $\%$ & $\mathrm{n}$ & $\%$ & $\mathrm{n}$ & $\%$ & 0.478 & 0.01 \\
\hline Baik & 21 & 70 & 6 & 20 & 2 & 6.7 & & \\
\hline $\begin{array}{l}\text { Kurang } \\
\text { Baik }\end{array}$ & 0 & 0 & 0 & 0 & 1 & 3.3 & & \\
\hline Total & 21 & 70 & 6 & 20 & 3 & 10 & & \\
\hline
\end{tabular}

Berdasarkan Tabel 4 Hasil uji chi square, menunjukkan bahwa nilai $p<0,05$ ada hubungan pemberian discharge planning dengan kecemasan pada pasien diabetes melitus di RS Mata "Dr.YAP" Yogyakarta. Hubungan pemberian discharge planning dengan kecemasan menunjukkan bahwa pemberian discharge planning yang baik menunjukkan menurunkan kecemasan pada pasien diabetes melitus. Responden yang diberikan discharge planning yang baik memiliki tingkat kecemasan tidak ada sebesar $70 \%$. Hasil uji statistik berdasarkan Tabel 4 didapatkan adanya hubungan yang signifikan antara pemberian discharge planning dengan kecemasan pada pasien diabetes melitus.

Menurut Videbeck, individu yang mengalami kecemasan akan mengalami respon fisiologis diantaranya adalah meningkatkan glikogenolisis menjadi glukosa bebas (3). Hal ini tentunya tidak diharapkan terjadi pada pasien dengan diabetes melitus yang menjalani perawatan, karena dengan meningkatnya kecemasan pasien maka akan meningkat pula kadar gula darah pasien. Hal ini dapat memperpanjang masa perawatan dan penyembuhan pasien diabetes melitus. Hasil penelitian ini adalah ada hubungan pemberian discharge planning pada pasien diabetes melitus di RS Mata "Dr.YAP" Yogyakarta, dimana dapat diketahui bahwa pemberian discharge planning yang baik mampu menurunkan kecemasan pada pasien diabetes melitus.

\section{SIMPULAN DAN SARAN}

Karakteristik pasien diabetes melitus yang diberikan discharge planning berdasarkan umur terbanyak adalah berusia 56-65 tahun sebanyak 11 responden (36.6\%), jenis kelamin terbanyak adalah perempuan sebanyak 18 orang (60\%), tingkat pendidikan terbanyak adalah perguruan tinggi sebanyak 12 orang (40\%) dan status pekerjaan terbanyak adalah tidak bekerja sebanyak 9 orang (30\%). Pemberian discharge planning pada pasien diabetes melitus di ruang rawat inap RS Mata "Dr.YAP" Yogyakarta adalah baik, sebanyak 29 responden (96,7\%). Tingkat kecemasan pada pasien diabetes melitus setelah diberikan 
discharge planning adalah tidak ada kecemasan sebanyak 21 responden (70\%). Pemberian discharge planning berhubungan dengan kecemasan pada pasien diabetes melitus di RS Mata "Dr.YAP" Yogyakarta.

Saran penelitian ini Bagi Rumah Sakit Mata "Dr.YAP"Yogyakarta pelaksanaan discharge planning di rumah sakit ini sudah berjalan baik sesuai dengan kebijakan rumah sakit dan standar operasional prosedur rumah sakit mata "Dr.YAP" Yogyakarta namun perlu dilakukan redisign form discharge planning yang mengacu pada teori. Bagi perawat di ruang rawat inap rumah sakit mata "Dr.YAP" Yogyakarta hendaknya perawat mengoptimalkan pemberian discharge planning terutama dalam memberikan penyuluhan kesehatan kepada pasien dan keluarga dapat menggunakan media leaflet yang berhubungan dengan kondisi pasien. Perawat mengembangkan diri dengan melanjutkan pendidikan formal. Untuk peneliti selanjutnya untuk peneliti selanjutnya agar meneliti faktor-faktor yang mempengaruhi pelaksanaan discharge planning pada pasien rawat inap seperti faktor personil, misal karakteristik perawat.

\section{DAFTAR PUSTAKA}

1. Bustan MN. Manajemen Pengendalian Penyakit Tidak Menular. Jakarta: Rineka Cipta; 2015.

2. Game FL, Apelqvist J, Attinger C, Hartemann A, Hinchliffe RJ, Londahl M, et al. IWGDF guidance on use of interventions to enhance the healing of chronic ulcers of the foot in diabetes 32. Diabetes Metab Res Rev. 2016;75-83.

3. Videbeck SL. Buku Ajar Keperawatan Jiwa. Jakarta: EGC; 2008.

4. Kozier B. Fundamental Keperawatan :Konsep, Proses \& Praktik. 7th ed. Jakarta: EGC; 2010.

5. Potter PA, Perry AG. Fundamentals of Nursing, Fundamental Keperawatan. 7th ed. Jakarta: Salemba Medika; 2009.

6. Indonesia KKR. Populasi lansia diperkirakan terus meningkat hingga tahun 2020. Diakses pada tanggal, 28. 2013.

7. Penelitian B, RI PKKK. Penyajian Pokok-Pokok Hasil Riset Kesehatan Dasar 2013. Jakarta: Kemenkes RI; 2014.

8. Soegondo S, Pradana S, Imam S. Penatalaksanaan Diabetes Melitus Terpadu. 2nd ed. Jakarta: Badan Penerbit FKUI; 2015.

9. Kusumawati F, Hartono Y. Buku Ajar Keperawatan Jiwa. Jakarta: Salemba Medika; 2010.

10. Machfoedz I. Metodologi Penelitian (Kuantitatif \& Kualitatif). Revisi. Yogyakarta;2016.

11. Lukman. Asuhan Keperawatan Pada Klien Dengan Gangguan Sistem Muskuloskeletal. Jakarta: Salemba Medika; 2009. 
12. Lutfa $U$, Maliya A. Faktor-faktor yang mempengaruhi kecemasan pasien dalam tindakan kemoterapi di Rumah Sakit Dr. Moewardi Surakarta. 2008;

13. Kaplan HI, Saddock BJ. Sinopsis Psikiatri. 8th ed. Jakarta.: Bina Rupa;

14. Laela S, Wahyuni E. Hubungan Riwayat Ansietas di Keluarga Terhadap Ansietas Mahasiswa Tingkat I Dalam Mempertahankan Beasiswa di Akper Manggala Husada. J IIm Keperawatan Altruistik. 2018;1(1):15-30.

15. Notoatmodjo S. Perilaku Kesehatan. Cetakan Ketiga. Revisi. 2007.

16. Azimatunnisa A, Kirnantoro K. Hubungan Discharge Planning dengan Tingkat Kesiapan Klien dalam Menghadapi Pemulangan di RS PKU Muhammadiyah Yogyakarta (Doctoral dissertation, STIKES'Aisyiyah Yogyakarta). 2011;

17. Notoatmodjo S. Pengantar IImu Perilaku Kesehatan Dan Pendidikan Kesehatan Gigi. Jakarta: EGC; 2010. 